\title{
The Narrative Structures of Glory and Glorification in the Fourth Gospel
}

Nielsen, Jesper Tang

Published in:

New Testament Studies

DOI:

10.1017/S0028688510000019

Publication date:

2010

Document version

Early version, also known as pre-print

Citation for published version (APA):

Nielsen, J. T. (2010). The Narrative Structures of Glory and Glorification in the Fourth Gospel. New Testament Studies, 56, 343-366. https://doi.org/10.1017/S0028688510000019 


\section{New Testament Studies}

http://journals.cambridge.org/NTS

Additional services for New Testament Studies:

Email alerts: Click here

Subscriptions: Click here

Commercial reprints: Click here

Terms of use : Click here

\section{The Narrative Structures of Glory and Glorification in the Fourth Gospel}

Jesper Tang Nielsen

New Testament Studies / Volume 56 / Issue 03 / July 2010, pp 343 - 366

DOI: 10.1017/S0028688510000019, Published online: 28 May 2010

Link to this article: http://journals.cambridge.org/abstract_S0028688510000019

How to cite this article:

Jesper Tang Nielsen (2010). The Narrative Structures of Glory and Glorification in the Fourth Gospel. New Testament Studies, 56, pp 343-366 doi:10.1017/S0028688510000019

Request Permissions : $\underline{\text { Click here }}$ 


\title{
The Narrative Structures of Glory and Glorification in the Fourth Gospel
}

\author{
JESPER TANG NIELSEN \\ University of Copenhagen, Det Teologiske Fakultet, Købmagergade 44-46, 1150 \\ København K, Denmark. \\ email:jtn@teol.ku.dk
}

\begin{abstract}
This article takes part in the reopened discussion of the Johannine $\delta \boldsymbol{o}_{\boldsymbol{\alpha}} \boldsymbol{\alpha} /$ $\delta o \xi \dot{\alpha} \zeta \in \imath v$ by interpreting the concept in light of the narrative structures in the Fourth Gospel. On the basis of Aristotle's definition of a whole and com-

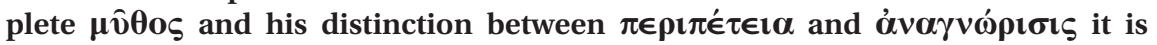
shown that the main structure in the Johannine narrative concerns humans' recognition of Jesus' identity as son of God. As a consequence of being firmly integrated in this narrative structure, the Johannine concept $\delta \boldsymbol{o}^{\xi} \boldsymbol{\alpha} / \boldsymbol{\delta} \boldsymbol{\alpha} \xi \dot{\alpha} \zeta \in \mathrm{l} v$ basically denotes divine identity and recognition. Opposing a contemporary trend in Johannine studies it is finally argued that $\delta \boldsymbol{o} \xi \alpha / \delta o \xi \dot{\alpha} \zeta \in \imath v$ in the Fourth Gospel should be understood within the normal narrative sequence.
\end{abstract}

Keywords: Fourth Gospel, Aristotle, narratology, recognition, glory, glorification

\section{Introduction}

There is good reason to celebrate that the Johannine concept of glory finally gets the attention it deserves. For decades the only monograph on the subject was Wilhelm Thüsing's Die Erhöhung und Verherrlichung Jesu im Johannesevangelium from 1960. ${ }^{1}$ But in 2007 two German theses appeared. The 747-page dissertation of Nicole Chibici-Revneanu is entirely devoted to a detailed exegetical exposition of all occurrences of $\delta$ ó $\xi \alpha$ and $\delta o \xi \dot{\alpha} \zeta \in$ iv in the Fourth Gospel in light of the Greek and Early Jewish background. ${ }^{2}$ Rainer Schwindt's 591-page habilitation Gesichte der Herrlichkeit focuses on the concept of glory in relation to the 'Son of Man' in the OT and Early Jewish literature and includes a treatment of the Pauline use of glory-terminology

1 Wilhelm Thüsing's Die Erhöhung und Verherrlichung Jesu im Johannesevangelium (NTA 21; Münster: Aschendorff, 1960).

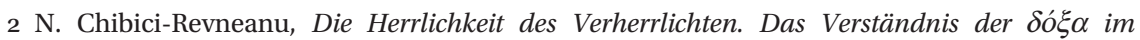
Johannesevangelium (WUNT 2/231; Tübingen: Mohr Siebeck, 2007). 
along with the Johannine one. ${ }^{3}$ That same year a keynote lecture at the SNTS conference supplemented these books. Jörg Frey presented his ingenious interpretation of the Johannine understanding of glory with special emphasis on its retrospective character. ${ }^{4}$ It is tempting to call 2007 a glorious year in Johannine scholarship.

All three studies excel in meticulous analyses and innovative interpretations, from which the following has benefited greatly. But despite the considerable length of both books not all aspects of the Johannine use of $\delta$ ó $\xi \alpha / \delta o \xi \alpha \zeta \in$ vv have been treated exhaustively. Unlike the intriguing interpretation of Jörg Frey, the recent monographs have not construed the Johannine glory-terminology in terms of the narrative plot of the Fourth Gospel. They do not account for the integration of $\delta o^{\prime} \xi \alpha / \delta o \xi \alpha \dot{\alpha} \in \in$ IV into the Johannine narrative and thereby they underestimate the originality and creativity in the Johannine reception of the concept. ${ }^{5}$ Consequently, all authors maintain the conventional translation glory/glorification (Herrlichkeit/Verherrlichung). ${ }^{6}$

Jörg Frey does relate the Johannine concept of glory to the structures of the gospel. To him it is the quintessence of Johannine theology that the gospel involves a genuine narrative process but at the same time transcends this structure. According to Frey, the Johannine narrative culminates in Jesus' glorification in the 'hour'. At this point he is attributed a $\delta$ ' $\xi \alpha$ that he did not possess beforehand. From this perspective the $\delta$ ó $\xi \alpha$ is projected onto the story of Jesus: 'Die $\delta \delta^{\prime} \xi \alpha$, die in der Schrift verheißen und in der österlichen Wirklichkeit erkannt wurde, kommt in dieser Sichtweise gerade dem Gekreuzigten zu-und von hier aus auch dem Irdischen, Fleischgewordenen und zuletzt auch dem Präexistenten'. ${ }^{7}$ In this interpretation the Johannine Jesus is from the beginning of the gospel conceived of in terms of the end result of the Johannine narrative. He carries, as it were, his own history throughout the gospel. ${ }^{8}$ As corollary Frey claims that the Johannine concept of $\delta$ ó $\xi \alpha$ is a consequence of the retrospective point of view of the Fourth Gospel: 'Das ganze Evangelium zeichnet den Weg des

3 R. Schwindt, Gesichte der Herrlichkeit. Eine exegetisch-traditionsgeschichtliche Studie zur paulinischen und johanneischen Christologie (HBS 50; Freiburg im Breisgau: Herder, 2007).

4 J. Frey, ““...dass sie meine Herrlichkeit schauen” (Joh 17.24). Zu Hintergrund, Sinn und Funktion der johanneischen Rede von der $\delta$ ó $\alpha$ Jesu', NTS 54 (2008) 375-97.

5 This is also to be said about the treatment in J. T. Nielsen, Die kognitive Dimension des Kreuzes. Zur Deutung des Todes Jesu im Johannesevangelium (WUNT 2/263; Tübingen: Mohr Siebeck, 2009) 90-111.

6 Significantly, Chibici-Revneanu uses a range of expressions to describe the Johannine $\delta$ ó $\xi \alpha /$

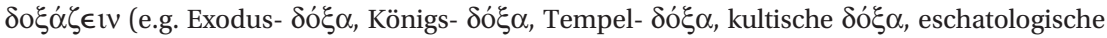
$\delta o ́ \xi \alpha$, Gerichts- $\delta$ ó $\xi \alpha$, lichthafte $\delta o ́ \xi \alpha$ ), but concludes that the translations 'Herrlichkeit' and 'Verherrlichung' best cover the Johannine use of $\delta$ ó $\xi \alpha / \delta o \xi \alpha \zeta \epsilon \in 1 v$. Chibici-Revneanu, Herrlichkeit, 640.

7 Frey, 'Herrlichkeit', 396.

8 Cf. Frey, 'Herrlichkeit', 390. 
Irdischen im Licht seiner $\delta$ ó $\xi \alpha$, d.h. in einer Perspektive, die den Zeugen erst im Rückblick, in der geistgewirkten Erinnerung und Schriftlektüre, erschlossen wurde'. ${ }^{9}$ In this way the concept is embedded in the same narrative structures that produce it. ${ }^{10}$ On the basis of a classical definition of a narrative plot the question arises if Frey's interpretation complies with the demands of a whole and complete narrative, or if it dissolves the narrative structures of the Fourth Gospel.

The objective of this study is to expose the structures that constitute the Fourth Gospel as a whole and complete narrative. The dominant feature of these structures is the recognition of God through Jesus. Salvation lies in this recognition. The $\delta$ ó $\xi \alpha / \delta$ o $\xi \alpha \zeta \epsilon \in$ v-terminology is used for expressing these ideas, which causes an innovative Johannine interpretation of the concept. It denotes divine identity and recognition.

The first task will be briefly to sketch out the semantic field of the $\delta$ ó $\xi \alpha /$ $\delta$ o $\xi \alpha \zeta_{\zeta} \in \mathrm{v} v$-terminology. The purpose is not to describe all possible meanings of the words but rather to locate the broad semantic potential that constitutes the general spectrum of possible applications. Secondly follows a presentation of classical narrative theory, which is the basis for a cursory analysis of the fundamental narrative course of the Fourth Gospel. The intention is to present the structures that constitute the overall meaning of the gospel narrative. Finally, the traditional semantic potential and the narrative structures will form the basis for an interpretation of the Johannine use of $\delta \delta^{\prime} \xi \alpha / \delta o \xi \alpha \dot{\alpha} \in \mathfrak{l}$. In conclusion it will be shown that the structures of a whole and complete narrative cannot include the narrative itself in its retrospective point of view.

\section{Traditional and Literary Background}

An extensive analysis of the semantic domains of כבד and $\delta$ ó $\xi \alpha / \delta o \xi \dot{\alpha} \zeta \in 1 V$ cannot be conducted within the frames of this study. ${ }^{11}$ Neither is it possible nor

9 Frey, 'Herrlichkeit', 382. Frey used to refer to this technique as 'hermeneutische Horizontverschmelzung'. Cf. J. Frey, Die johanneische Eschatologie II. Das johanneische Zeitverständnis (WUNT 110; Tübingen: Mohr Siebeck, 1998) 247-83.

10 Cf. Frey, 'Herrlichkeit', 395-6.

11 Cf. Chibici-Revneanu, Herrlichkeit, 335-510; Schwindt, Gesichte, 13-105; C. C. Newman, Paul's Glory-Christology: Tradition and Rhetoric (NTS 69; Leiden/New York: Brill, 1992) 17-153. Older scholarship mainly consists of articles in dictionaries and encyclopaedias but a few linguistic investigations should be mentioned. A. F. von Gall, Die Herrlichkeit Gottes. Eine biblisch-theologische Untersuchung ausgedehnt über das Alte Testament, die Targume, Apokryphen, Apokalypsen und das Neue Testament (Giessen: J. Ricker, 1900); W. Caspari, Die Bedeutungen der Wortsippe kbd im Heräischen (Leipzig: A. Deichert, 1908); J. Schneider, Doxa. Eine bedeutungsgeschichtliche Studie (Gütersloh: C. Bertelsmann, 1932); H. Kittel, Die Herrlichkeit Gottes. Studien zu Geschichte und Wesen eines Neutestamentlichen Begriffs (BZNW 16; Giessen: A. Töpelmann, 1934). 
necessary to locate the precise literary background for the Johannine concept of $\delta \delta^{\prime} \xi \alpha .^{12}$ At this point a simplified summary of its general semantic potential suffices. ${ }^{13}$

It is beyond doubt that כבד in the Hebrew Bible forms the background for the concept of glory. The original meaning of the root כבד is 'weight' or 'heavy', but besides a few fixed expressions such as 'hard of hearing' (Isa 6.10; 59.1; Zech 7.11), 'weak-sighted' (Gen 48.10) or the phrase 'the hand of the Lord was heavy upon' (e.g. 1 Sam 5.6) its original meaning is very seldom found in the biblical writings. ${ }^{14}$ Instead it belongs to one of two semantic domains. Either כבד functions within the ancient honour-shame system and designates a desirable status in the social hierarchy. ${ }^{15}$ Or it denotes a certain way of appearing that corresponds to a superior position. Following the former meaning the noun כבוד can be used about everything that evokes recognition and establishes high social status, for example, wealth (Gen 31.1), belongings (Job 19.9), or payment (Num 22.17). Consequently, verbal expressions of כבד or the equivalent idiom 'to give כבוד) (נתן כבד) stand for social recognition, for example, when God calls forth recognition of himself as God by his mighty deeds (Exod 14.4). ${ }^{16}$ The latter denotation of the term primarily concerns the appearance of God. Where he appears, his כבוד is present, for example, on Sinai (Exod 24.16-17), in the tabernacle (Exod 40.34-5), or in the temple (1 Kings 8.10-11). ${ }^{17}$ In apocalyptic writings (e.g. 1 Enoch) and in some scrolls from Qumran (e.g. 4QSS) God's כבוד is present in heaven.

12 Among the recent publications it is agreed that the immediate influence comes from the LXXversion of Isaiah. Schwindt, Gesichte, 322; Chibici-Revneanu, Herrlichkeit, 495-6; Frey, 'Herrlichkeit', 383. Even though LXX Isaiah may be the direct inspiration for the Fourth Gospel's use of $\delta$ ó $\xi \alpha / \delta o \xi \alpha \zeta \in$ lv there is much more involved in the Johannine concept than can be derived from Isaiah or any other specific source.

13 Cf. Nielsen, Die kognitive Dimension des Kreuzes, 90-111. This approach differs from the newest contributions. R. Schwindt investigates the history of tradition concerning glory in the Hebrew Bible and its reception. His main interest is the possible development of an idea of a human or divine medium for the divine glory. Schwindt, Gesichte, 13-105. N. Chibici-Revneanu defines the contemporary understanding of glory in a variety of different concepts and places the various Johannine uses of the term in relation to these specific semantic domains. Chibici-Revneanu, Herrlichkeit, 335-519.

14 Cf. C. Dohmen and P. Stenmans, 'כבד', ThWAT 4.13-22 (14-17); Schwindt, Gesichte, 13-14.

15 Cf. B. J. Malina, The New Testament World: Insights from Cultural Anthropology (Louisville: Westminster/John Knox, 2d rev. ed. 1993), 28-50.

16 The conjugation niphal carries a reflexive or passive meaning. W. Gesenius and E. Kautzsch, Hebräische Grammatik (Hildesheim: Georg Olm, 1962) §51,2.

17 From a literary perspective this idea belongs to the priestly layer. C. Westermann, 'Die Herrlichkeit Gottes in der Priesterschrift', Forschung am Alten Testament. Gesammelte Studien II (Munich: Kaiser, 1974) 115-37; U. Struppe, Die Herrlichkeit Jahwes in der

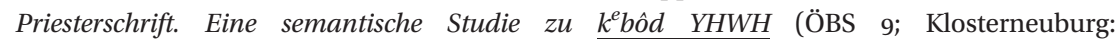
Österreichisches Katholisches Bibelwerk, 1988); B. Janowski, Sühne als Heilsgeschehen. Traditions- und religionsgeschichtliche Studien zur priesterschriftlichen Sühnetheologie (WMANT 55; Neukirchen-Vluyn: Neukirchner, 2d rev. ed. 2000), 303-38. 


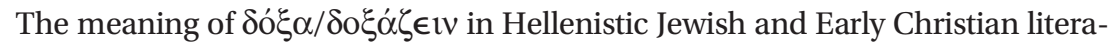
ture is a product of the Greek translation of the OT. Before the LXX $\delta$ ó $\xi \alpha$ had the meaning 'expectation', 'opinion', or 'repute'. The verb $\delta$ o $\xi \alpha \zeta \zeta \in 1 v$ simply meant 'think' or 'imagine'. ${ }^{18}$ In the LXX the words basically took over the semantic value of כבד. The reason for the translators' choice has been a matter of discussion. Especially the rendering of כבוד יהוה with $\delta$ כó $\xi \alpha$ אvpíov, which is not consistent with $\delta$ ó $\xi \alpha$ 's classical meaning, has attracted attention. ${ }^{19}$ It seems likely, though, that the classical meaning 'opinion' and hence 'the opinion which others have of one', that is, 'repute', caused $\delta$ ó $\xi \alpha$ to translate כבוד when it denotes social status. Consistency made the translators render all instances of כבוד in the same way.

Most Hellenistic Jewish and Early Christian writers use $\delta$ ó $\xi \alpha / \delta o \xi \dot{\alpha} \zeta \in 1 v$ according to the LXX. Only a few characteristic aspects from the later literature need to be mentioned. Sapiential writings make a distinction between false and true $\delta$ ó $\xi \alpha$. True $\delta$ ó $\xi \alpha$ derives from a right relation to God and his wisdom (e.g. Sir $1.11 ; 14.27 ; 44.13)$. False $\delta o ́ \xi \alpha$ only concerns recognition from humans (e.g. Sir $3.10 ; 40.27$ ). For that reason the two may exclude each other (Sir 4.21; Est 4.21). This corresponds to the apocalyptic understanding that God's glory exclusively belongs to heaven whereas human glory dominates in the world (e.g. 2 Bar $51.5,16)$. The righteous, however, will receive the heavenly glory in the end time (e.g. 2 Bar 15.8; 48.49-50).

Though Philo primarily uses $\delta$ ó $\xi \alpha / \delta o \xi \alpha \dot{\alpha} \zeta \in$ vv according to its classical meaning, he in two places comments on the descent of God's $\delta$ ' $\xi \alpha$ on Sinai (Spec. Leg. I 45; Quaest. Ex. II 45, 47). ${ }^{20}$ In his interpretation he insists on a distinction between

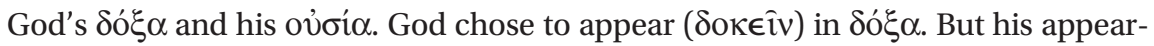
ance $\left(\delta \delta^{\prime} \xi \alpha\right)$ is not a manifestation of his essence (ov่ $\sigma i \alpha$ ), which is not accessible to physical sight but only to noetic contemplation (Quaest. Ex. II 45-47).

Notwithstanding the differences, the main result of these glimpses into the background for the Johannine terminology is that the semantic field of כבד and accordingly $\delta$ ó $\xi \alpha / \delta o \xi \alpha \zeta \in \mathfrak{\alpha}$ can be divided into two parts. One is the social-hierarchical understanding of $\delta o^{\prime} \xi \alpha / \delta o \xi \alpha \dot{\alpha} \in \mathfrak{\omega}$ as a relational status and recognition. The other is the aesthetic idea of $\delta$ ó $\xi \alpha$ as divine appearance.

\section{Narrative Structures}

As stated in the introduction, it is one thing to reconstruct the semantic potential of the terms $\delta$ ó $\xi \alpha / \delta$ o $\xi \alpha \zeta \in$ iv but quite another to define their meaning in a concrete context. When the concept is incorporated into the

18 LSJ, 444; cf. Chibici-Revneanu, Herrlichkeit, 336-53.

19 Cf. von Gall, Herrlichkeit, 23-4; Caspari, Bedeutungen, 80-6; Schneider, Doxa, 69-70; Kittel, Herrlichkeit, 63; Newman, Glory-Christology, 147.

20 Cf. Chibici-Revneanu, Herrlichkeit, 345-8. 
Fourth Gospel, its exact meaning will be a product of the structures that constitute the Johannine narrative. While the semantic potential of $\delta$ ó $\xi \alpha / \delta o \xi \dot{\alpha} \zeta \in 1 v$ stems from the common use in Early Jewish and Christian writings, the inherent narrative structures of the Fourth Gospel actualize specific parts of this potential.

One of the indispensable elements of a narrative is action. Something must happen in a story otherwise it is not a story at all. In his Poetics Aristotle presents this criterion as a demand for the construction of a good tragedy: it must have a whole and complete plot $(\mu \hat{v} \theta 0 \varsigma)$ which includes beginning, middle and end (ArPoet 1450b25). ${ }^{21}$ Or, to put it in another way, there must be a change $(\mu \in \tau \alpha \beta \alpha \dot{\alpha} \lambda \lambda \in 1 v / \mu \in \tau \alpha \dot{\alpha} \beta \alpha \sigma i \varsigma)$ in the course of a whole and complete narrative (ArPoet 1451a15). The transformation composes the narrative structure from beginning through the middle to the end and relates the three phases to each other. A beginning is an initial situation that does not necessarily presuppose anything but leads with necessity or for the most part (ArPoet 1450b29) into a new situation, the middle. Logically, the middle follows from the beginning, and consequently presupposes this preceding situation. The middle, on the other hand, leads necessarily or usually into the end. But from the end nothing follows with necessity (ArPoet 1450b25-34). Narratologically it is important that these three phases, and not the involved persons, constitute the narrative coherence (ArPoet 1450a15). A person cannot guarantee a narrative development. For that reason the narrative structure and not the protagonist makes up the plot.

Aristotle makes another important distinction when he introduces the con-

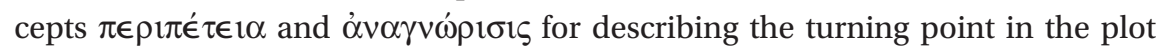
(ArPoet 1452a23-30). Good plots, Aristotle insists, do not develop gradually from beginning through the middle to the end but involve a turning point, $\pi \in \rho \imath \tau \epsilon \epsilon \in 1 \alpha$, that marks the passage between two opposites, for example, from happiness to unhappiness. But where $\pi \in \rho \imath \tau \epsilon \epsilon \in 1 \alpha$ is a turning point in the pragmatic dimension of the story because it always describes a passage from one con-

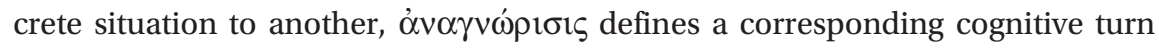
from ignorance to knowledge. In the best plots the two turning points coincide as is the case in the model drama, Oedipus Rex. In the sixteenth chapter of his treatise Aristotle even presents a taxonomy of the different ways to provoke

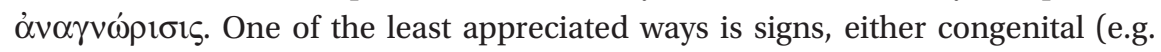
birthmarks) or achieved (e.g. scars), whereas an $\dot{\alpha} \alpha \gamma v \omega \dot{p}$ ıøıৎ that ensues from the structure of the plot is considered to be among the best. ${ }^{22}$

21 On Aristotle's Poetics see the commentaries, e.g., G. F. Else, Aristotle's Poetics: The Argument (Leiden: Brill, 1957); D. W. Lucas, Aristotle Poetics: Introduction, Commentary, and Appendixes (Oxford: Clarendon, 1968); S. Halliwell, The Poetics of Aristotle: Translation and Commentary (Chapel Hill: University of North Carolina, 1985); and the collection of essays A. O. Rorty, ed., Essays on Aristotle's Poetics (Oxford: Princeton University, 1992).

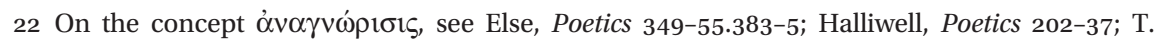
Cave, Recognitions: A Study in Poetics (Oxford: Clarendon, 1988) 28-46. 
From a narratological point of view the main achievement of the distinction

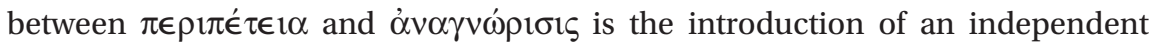
cognitive level in the plot. ${ }^{23}$ This cognitive level is to be seen in contradistinction to a pragmatic level, which is the concrete actions and events of the narrative. ${ }^{24} \mathrm{~A}$ whole and complete story may just take place on the pragmatic level and consist of a course of pragmatic actions. But some stories, which Aristotle finds better, also have a cognitive course that concerns the understanding of the pragmatic events and actions (ArPoet 1452a31). ${ }^{25}$ The cognitive level is dependent on the pragmatic one because it refers to it and may be influenced by it, as can be

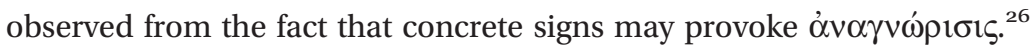

In conclusion, Aristotle defines the most important element of a story as the plot $(\mu \hat{v} \theta 0 \varsigma)$ which is a narrative structure with beginning, middle, and end (ArPoet 1450a15). To be good the plot must include at least a pragmatic turning

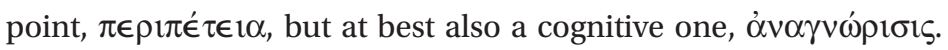

Aristotle's Poetics has been extremely important to narratological theories. It has been expanded and refined by later theorists but it is still a sound theoretical basis for a presentation of the Johannine plot. When the Aristotelian concepts and definitions are applied to the Fourth Gospel, the narrative structure that is fundamental to the Johannine understanding of $\delta$ ó $\xi \alpha / \delta o \xi \alpha \dot{\alpha} \in \mathfrak{i v}$ emerges.

\section{The Narrative Structures of the Fourth Gospel}

There have been several attempts to apply Aristotelian narratological terminology to the Fourth Gospel. Especially the concept of $\alpha v \alpha \gamma v \omega$ proıs has been subject to intense studies. ${ }^{27}$ It is characteristic that they focus on

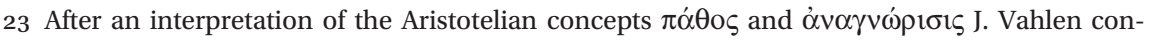
cludes that 'die Erkennung, ganz so wie das $\pi \alpha \dot{\theta} \theta \varsigma \varsigma$, als ein einzelnes Moment in dem Gange der Handlung betrachtet wird, das nicht bloß an dem Knotenpunkte der $\mu \varepsilon \tau \dot{\alpha} \beta \alpha \sigma 1 \varsigma$, sondern auch, wie z. B. in den Choëphoren, an andern Stellen und an mehrern zugleich eintreten kann...' J. Vahlen, Beiträge zu Aristoteles' Poetik (Berlin: Teubner, 1914) 57.

24 So the terminologically imprecise but narratologically important semiotic interpretation of the

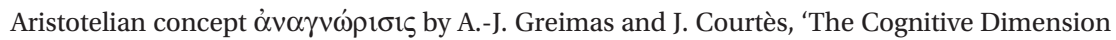
of Narrative Discourse', New Literary History 7 (1976) 433-47.

25 The two levels do not correspond to the Aristotelian distinction between simple ( $\dot{\alpha} \pi \lambda \mathrm{o} \hat{\varsigma} \varsigma$ ) and complex ( $\pi \in \pi \lambda \in \gamma \mu \epsilon \in \mathrm{v} O \zeta)$ plots as A.-J. Greimas and J. Courtès seem to think. Greimas and Courtés, 'Dimension', 339.

26 Cf. A.-J. Greimas and J. Courtés, Sémiotique. Dictionnaire raisonné de la théorie du langage (Paris: Hachette Supérieur, 1993), 'Cognitif'.

27 Extensively by K. B. Larsen, Recognizing the Stranger: Recognition Scenes in the Gospel of John (Biblical Interpretation Series 93; Leiden/Boston: Brill, 2008); but see also the works of R. A. Culpepper, 'The Plot of John's Story of Jesus', Int 49 (1995) 347-58; Culpepper, The Gospel and Letters of John (IBT; Nashville: Abingdon, 1998) 72-86. On the use of Aristotle in Johannine studies, cf. J. T. Nielsen, 'Resurrection, Recognition, Reassuring: The Function of 


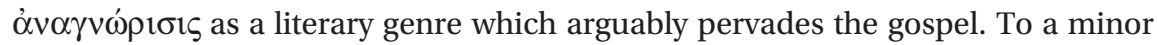
degree the exegetes place $\alpha v \alpha \gamma v \omega ́ p ı \sigma \varsigma s$ in relation to the overall structure of the gospel. The objective of this study is to define the Johannine plot according to Aristotle's idea of a whole and complete narrative and expose how these narrative structures determine the meaning of $\delta$ ó $\xi \alpha / \delta o \xi \alpha \dot{\alpha} \in \mathfrak{l v} .^{28}$

The narrative beginning is constructed as the ultimate beginning in the Fourth Gospel. In the beginning the divine logos is situated in a divine sphere where it enjoys the closest possible relation to God (1.1-2). The transition to the middle phase happens in the incarnation (1.14). Through remarks in the rest of the gospel it becomes obvious that God in the beginning initiates a mission by sending his son to carry out a certain task. ${ }^{29}$ Jesus repeatedly describes himself as the one that is sent and has a duty to fulfil, which can be expressed with

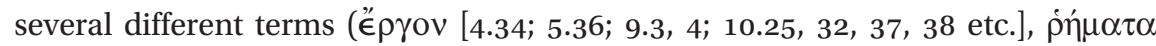

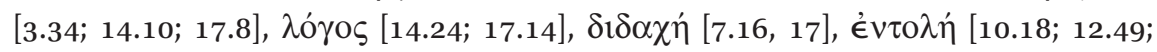
15.10], $\theta \dot{\epsilon} \lambda \eta \mu \alpha[4.34 ; 5.30 ; 6.38])$. Consequently, he refers to God in expressions

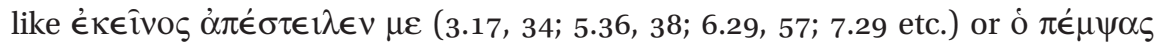

Jesus' Resurrection in the Fourth Gospel', The Resurrection of Jesus in the Gospel of John (ed. C. R. Koester and R. Bieringer; WUNT 222; Tübingen: Mohr Siebeck, 2008) 177-208.

28 Most often the gospel structure has been defined according to other criteria. Traditionally, the character of Jesus' activity lays the ground for dividing the narrative into two halves with a turning point between chs. 12 and 13, e.g., 'Die Offenbarung der $\delta o ́ \xi \alpha$ vor der Welt' and 'Die Offenbarung der $\delta o ́ \xi \alpha$ vor der Gemeinde', R. Bultmann, Das Evangelium des Johannes (KEK 2; Göttingen: Vandenhoeck \& Ruprecht, 1941); 'The Book of Signs' and 'The Book of Passion', C. H. Dodd, The Interpretation of the Fourth (Cambridge: Cambridge University, 1953); 'The Book of Signs' and 'The Book of Glory', R. Brown, The Gospel according to John (AB 29; New York: Doubleday, 1966). Other scholars use other criteria and suggest other structures, cf. the survey of 24 different proposals in G. Mlakuzhyil, The Christocentric Literary Structure of the Fourth Gospel (AnBib 117; Rome: Editrice pontificio istitutio biblico, 1987) 17-85. All these approaches differ from the present one by finding the structuring criteria on the surface of the gospel text (e.g. geographical, chronological, numerical, or liturgical). The Aristotelian structure organizes the story into a whole and complete narrative and is not necessarily reflected in, say, the geographical or chronological structure of the gospel. Contrariwise, neither the change in Jesus' activity nor any of the other proposed criteria constitute the coherence of the Johannine narrative.

29 On the prominent sending theme in the Fourth Gospel, see, e.g., P. Borgen, 'God's Agent in the Fourth Gospel', Religions in Antiquity (ed. J. Neusner; Leiden: Brill 1968) 137-48; J. A. Bühner, Der Gesandte und sein Weg im 4. Evangelium (WUNT 2/2; Tübingen: J. C. B. Mohr [Paul Siebeck], 1977); E. Haenchen, '“Der Vater der mich gesandt hat"', NTS 9 (1962-63) 208-16; J. P. Miranda, Die Sendung Jesu im vierten Evangelium. Religions- und theologiegeschichtliche Untersuchungen zu den Sendungsformeln (SBS 87; Stuttgart: Katholisches Bibelwerk, 1977); R. Schnackenburg, '"Der Vater, der mich gesandt hat." Zur johanneischen Christologie', Anfänge der Christologie. FS F. Hahn (ed. C. Breytenbach and H. Paulsen; Göttingen: Vandenhoeck \& Ruprecht, 1991) 275-91. 
$\mu \in(4.34 ; 5.23,24,30,37 ; 6.38,39,44$ etc.). These statements imply that the commissioning takes place in the initial narrative phase and is background for the incarnation that necessarily leads into the middle phase of the plot.

If the main part of the initial phase is the commissioning of Jesus, the content of the middle phase is the execution of the ordered task. The overall purpose of Jesus' earthly life is the salvation of humankind. Jesus is sent to give eternal life to the believers $(3.16,17 ; 6.39,40 ; 17.2 \mathrm{cf} .10 .10,28) .{ }^{30}$ Even if this is the reason for his incarnation and the content of his mission, it cannot be separated from another task that can be conceived of as a necessary precondition of the main task. Jesus must provoke faith because only believers receive eternal life. He cannot fulfil God's command and provide salvation for humankind if he is not met with faith by the humans he addresses. As a matter of fact, these two parts of Jesus' mission are so intimately connected that faith is identified with eternal life: 'And this is eternal life, that they may know you, the only true God, and Jesus Christ whom you have sent' (17.3). When the precondition of faith in Jesus as God's son and envoy is established, eternal life is already present (cf. $3.36 ; 5.24 ; 6.47 ; 11.25$ ). Accordingly, the main task is not dominant in the plot. ${ }^{31}$ The leading theme is that Jesus tries to win faith. Through his deeds $(5.36 ; 9.3$, $4 ; 14.10,11)$ and words $(7.16,17 ; 12.49 ; 14.10,24)$ he intends to reveal his close relation to God and his own divine character in order to be recognized as God's son and emissary. Recognition of Jesus' divine authority therefore implies recognition of God as the authority behind Jesus. When Jesus is recognized as God's agent who represents God in his words and deeds, God is recognized as being revealed in the words and deeds of Jesus $(14.9,10)$. When this happens, Jesus fulfils his role as saviour. Recognition of the divine community between Jesus and his father involves participation in this community (14.20; 17.21, 23; cf. 10.38; 14.10, 11) and consequently eternal life.

On the basis of the interpretation of Aristotle's narratological theory it is possible to place the dominant part of Jesus' mission on the cognitive level of the nar-

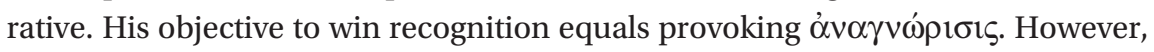
it is also included in his mission that he must give his life in order to take it back

30 Cf. the so called 'Präponderenz des göttlichen Heilswillen'. J. Blank, Krisis. Untersuchungen zur johanneischen Christologie und Eschatologie (Freiburg i.B.: Lambertus, 1964) 88. J. Blank coined this concept in opposition to R. Bultmann's idea that Jesus' coming and going is the krisis of the world in the Fourth Gospel. R. Bultmann, Das Evangelium des Johannes (Göttingen: Vandenhoeck \& Ruprecht, 1941) 111-13; Bultmann, Theologie des Neuen Testaments (Tübingen: J. C. B. Mohr [Paul Siebeck], 9th ed. 1984) 390-1.

31 In M. W. G. Stibbe's application of A.-J. Greimas's actantial model on the Fourth Gospel this is not entirely clear because he does not distinguish between the pragmatic and cognitive level. M. W. G. Stibbe, "Return to Sender”: A Structuralist Approach to John's Gospel', The Interpretation of John (ed. J. Ashton; Edinburgh: T. \& T. Clark, 1997) 261-78; cf. Stibbe, John's Gospel (London/New York: Routledge 1994) 32-53. 
(10.18). For that reason Jesus pronounces the completion of his task from the cross (19.30). The crucifixion is embedded in the narrative and it takes on a decisive role because it functions as the $\pi \epsilon \rho \imath \epsilon \epsilon \epsilon 1 \alpha$ in the course of Jesus' life. ${ }^{32}$ After his death he is resurrected, returns to the father, and is taken back into the divine community from which he was sent $(7.33 ; 8.14,21,22 ; 13.3,33,36$ etc.). When he transits from earth into the heavenly realm he is transformed into the divine state of being that he had in the initial narrative phase. In this way his death is the transition to the end phase of the plot.

In contrast to stories like Sophocles' Oedipus Rex, the $\pi \in \rho \imath \epsilon \epsilon \epsilon 1 \alpha$ and

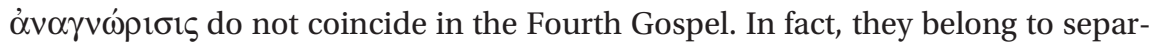
ate structures of the plot. The $\pi \in \rho \imath \tau \epsilon \epsilon \in 1 \alpha$ takes place in the passion when Jesus, because of his completion of his mission on the cross, is transformed from his

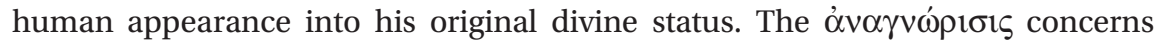
humans' relation to Jesus and his father. They turn from ignorance of Jesus' identity to faith when they recognize him as son of God. As a corollary they leave a status of ignorance of God and enter an insightful status by realizing that Jesus

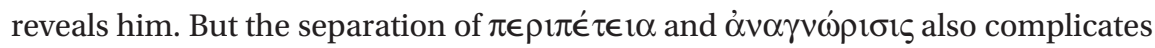
the Johannine plot structure. Jesus does not provoke a full recognition during his lifetime in the narrative middle. He gathers the humans that are given him from God (17.2) but even they are not able to follow him through his passion. As a matter of fact, Jesus himself rejects their faith with a reference to their future desertion (16.31-2). After the crucifixion the disciples and adherents of Jesus are not portrayed as committed believers. Mary Magdalene meets Jesus in Gethsemane but she does not recognize him and mistakes him for an ordinary man, namely the gardener. When she recognizes his voice, she still addresses him as a human with the common title 'Rabbi' (20.16; cf. 3.26). ${ }^{33}$ Even the ideal figure of the Beloved Disciple does not believe until he sees the empty tomb

32 Cf. R. A. Culpepper, Anatomy of the Fourth Gospel: A Study in Literary Design (Philadelphia: Fortress, 1983) 88; P. Bühler, 'Ist Johannes ein Kreuzestheologe? Exegetisch-systematischer Bemerkungen zu einer noch offenen Debatte', Johannes-Studien. Interdisziplinäre Zugänge zum Johannes-Evangelium. FS J. Zumstein (ed. M. Rose; Neuchâtel: Secrétariat de l'Université, 1990) 191-207 (esp. 197-202).

33 It is often claimed that Mary Magdalene has an extraordinarily intimate relation to Jesus because she meets him in a very delicate situation after his resurrection but before his ascension, e.g., M. R. D'Angelo, 'A Critical Note: John 20.17 and the Apocalypse of Moses 31', JThS 41 (1990) 529-36. But this interpretation overlooks that she in fact misunderstands him and is rejected by him. Cf. M. Theobald, 'Der johanneische Osterglaube und die Grenzen seiner narrativen Vermittlung (Joh 20)', Von Jesus zum Christus. Christologische Studien, FS P. Hoffmann (ed. R. Hoppe and U. Busse; BZNW 93; Berlin/New York: de Gruyter, 1998) 93-123 (esp. 110-11). 
(20.8). ${ }^{34}$ Jesus does not find true faith and recognition before his resurrection. ${ }^{35}$ In the middle part of the plot he fails to obtain full óv $\alpha \gamma v \omega$ proı $\varsigma^{36}$

When the $\pi \epsilon \rho \imath \epsilon \epsilon \in 1 \alpha$ has brought Jesus back into his original state, there is no doubt that he is divine. This is the end phase of the narrative into which his resurrection and ascension led (cf. $3.14 ; 8.28 ; 12.32-3$ ). In this phase humans immediately recognize that Jesus is divine. But the resurrection witnesses need proof that the divine being before them is identical with the incarnated and crucified

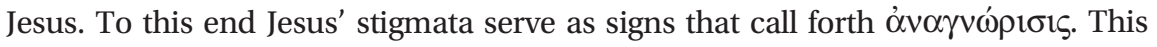
point is spelled out in two episodes in the end phase of the plot. First, Jesus suddenly appears to the disciples though the doors are closed (20.19). He shows his stigmata to identify himself (20.20a). This evokes the disciples' joy and recognition of the Lord (20.20b). They recognize that the incarnated earthly Jesus was in fact God's son. The scene is repeated for Thomas, as it were. Thomas very explicitly states the purpose of the stigmata. If they are not present on the resurrected divine being, Thomas cannot believe (20.25). When the resurrected Jesus appears a week later and identifies himself by means of the stigmata (20.27), Thomas responds by confessing to Jesus' identity. 'My Lord and my God' (20.28). In the end phase of the plot full $\alpha v \alpha \gamma v \omega ́ p ı ı ı \varsigma$ is present and Jesus' mission is completed. ${ }^{37}$

According to Aristotle signs are one of the worst ways to provoke recognition. It is much better if the recognition ensues from the plot. In the Fourth Gospel the

34 On the function of the Beloved Disciple as an ideal for the Johannine Community, see M. Theobald, 'Der Jünger, den Jesus liebte. Beobachtungen zum narrativen Konzept der johanneischen Redaktion', Geschichte-Tradition-Reflexion, FS M. Hengel, Bd. III. Frühes Christentum (ed. H. Cancik, H. Lichtenberger, and P. Schäfer; Tübingen: J. C. B. Mohr [Paul Siebeck], 1996) 219-55 (esp. 242-7). This understanding of the Beloved Disciple stands even without M. Theobald's literary theory.

35 Cf., e.g., Haenchen, 'Der Vater, der mich gesandt hat', 212-13; Theobald, 'Der johanneische Osterglaube', 118; C. Dietzfelbinger, Abschied des Kommenden. Eine Auslegung der johanneischen Abschiedsreden (WUNT 95; Tübingen: J. C. B. Mohr [Paul Siebeck], 1997) 85; C. Welck, Erzählte Zeichen. Die Wundergeschichten des Johannesevangeliums literarisch untersucht. Mit einem Ausblick auf Joh 21 (WUNT 2/69; Tübingen: J. C. B. Mohr [Paul Siebeck], 1994), 124-5, 127.

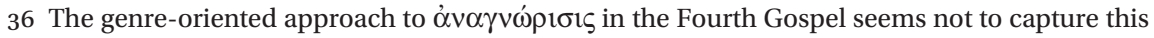
aspect; see, e.g., Larsen, Recognizing the Stranger. It may be another instance of Johannine 'genre bending', cf. H. W. Attridge, 'Genre Bending in the Fourth Gospel', JBL 121 (2002) 3-21.

37 That Thomas's confession is the culminating $\alpha v \alpha \gamma v \omega$ ' Culpepper, 'The Plot of John's Story of Jesus', 356; Culpepper, Gospel, 85; Stibbe, Gospel, 36, cf. J. G. van der Watt, 'The Cross/Resurrection-Events in the Gospel of John with Special Emphasis on the Confession of Thomas (20.28)', Neot. 37 (2003) 127-45; C. R. Koester, 'The Death of Jesus and the Human Condition: Exploring the Theology of John's Gospel', Life in Abundance: Studies of John's Gospel in Tribute to Raymond E. Brown (ed. John R. Donahue; Collegeville, MN: Liturgical, 2005) 141-57; cf. Koester, 'Why Was the Messiah Crucified? A Study of God, Jesus, Satan, and Human Agency in Johannine Theology', The Death of Jesus in the Fourth Gospel (ed. G. van Belle; BEThL 200; Leuven: Leuven University, 2007) 163-80 (esp. 178-9). 
sign that provokes recognition is a natural consequence of the narrative course of beginning, middle, and end. Only because Jesus' death completes the middle phase and lets the resurrection introduce the end phase, can his stigmata

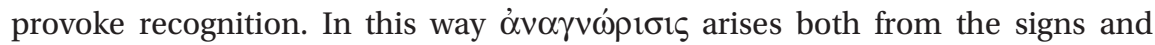
from the plot itself.

To sum up on the Johannine narrative structure: In the beginning Jesus is the eternal logos with his father in the heavenly divine community. He is sent to give humans eternal life by including them into this unity. The transition from beginning to middle happens in the incarnation. In order to complete his mission Jesus tries to provoke recognition of himself as God's son and envoy in the narrative middle phase. He fulfils his task when he is crucified because the crucifixion concludes the middle in a way that leads necessarily into the end phase. The narrative end takes its beginning when Jesus re-enters into his position with his divine father. When he subsequently appears to the disciples his identity as son of God is undoubted. His stigmata, however, function as signs that he is identical with the crucified Jesus. Thereby they provoke the disciples' recognition of Jesus' identity which immediately incorporates them into the divine community and results in eternal life. This accomplishes the salvific purpose of Jesus' mission.

\section{The Narrative Structure of Glory and Glorification}

On the basis of the fundamental narrative structure it is possible to detect

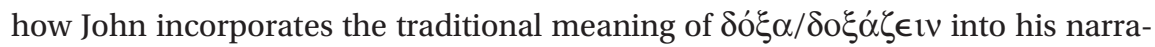
tive, thereby constructing a specific Johannine understanding of the terms. One of the salient features of the Fourth Gospel is that it applies the terminology $\delta \xi^{\prime} \alpha /$ $\delta o \xi \dot{\alpha} \zeta \in I V$ to almost all important elements of the narrative. It is used both about Jesus' divinity and about the recognition of him; it denotes the return to the heavenly situation as well as the carrying out of God's command. The alleged exclusive character of Johannine language and style is not least a result of the extended use of $\delta$ ó $\xi \alpha / \delta o \xi \alpha \dot{\alpha} \epsilon \in v^{38}{ }^{38}$

To approach the exegetical problems concerning the notion $\delta$ ó $\xi \alpha / \delta o \xi \dot{\alpha} \zeta \in 1 v$ in the Fourth Gospel it is expedient to systematize the terminology according to the persons and figures involved. The noun $\delta$ ó $\xi \alpha$ occurs 19 times in the gospel. First of all it is related to Jesus in several ways. He has a $\delta$ ó $\xi \alpha$ that the believers perceive $(1.14 ; 2.11)$. From the foundation of the world he had a $\delta$ ó $\xi \alpha$ with the father $(17.5$, 22, 24), which Isaiah saw in the temple (12.41). Secondly, God has a $\delta$ ' $\xi \alpha$ to which Lazarus' illness stands in a peculiar relation ( $(\dot{\pi} \hat{\rho})(11.4,40)$. Thirdly, there are a number of instances of giving and receiving $\delta$ ó $\xi \alpha$. Jesus neither receives nor asks for $\delta$ ó $\xi \alpha$ from humans $(5.41 ; 7.18 ; 8.50,54)$. Contrariwise, some humans do not

38 Cf. N. R. Petersen, The Gospel of John and the Sociology of Light: Language and Characterization in the Fourth Gospel (Valley Forge, PA: Trinity, 1993). 
seek $\delta$ ó $\xi \alpha$ from God but from each other $(5.44 ; 12.43)$. Nevertheless, the Jews demand that the man born blind give $\delta$ ó $\xi \alpha$ to God $(9.24) .^{39}$

The use of the verb is easier to systematize but actually more complicated. It occurs 23 times and can be organized into three groups. First, Jesus is subject and God object of the act of $\delta$ o $\xi \alpha \zeta \zeta \in I V(13.31,32 ; 14.13 ; 17.1,4)$. Secondly, God is subject and Jesus object of the act $(7.39 ; 8.54 ; 12.16,23,28 ; 13.32 ; 17.1,5)$. Finally, God and/or Jesus are object and a third party (the disciples, the Paraclete, Lazarus' illness or something else) is subject $(11.4 ; 13.31 ; 15.8 ; 16.14$; 17.10; 21.19).

What complicates the Johannine use of the terms is the fact that the noun expresses different ideas and the verb denotes different acts in an intricate relation between the three participating parties (God, Jesus, and humans). The exegetical task is to clarify when the noun expresses which ideas, and how the acts are related.

\subsection{Glory in the Narrative Structure}

The noun $\delta$ ó $\xi \alpha$ takes up different roles in all three narrative phases. Most significantly, the understanding of Jesus' $\delta$ ó $\xi \alpha$ and notably its accessibility varies in the course of the narrative. From the three verses concerning perception of Jesus' $\delta$ ó $\xi \alpha(1.14 ; 2.11 ; 12.41)$ it is manifest that he has a $\delta$ ó $\xi \alpha$ that is not directly visible. Before the incarnation his $\delta$ ó $\xi \alpha$ was revealed to the prophet Isaiah in the temple in Jerusalem (12.41)..$^{40}$ The evangelist interprets the theophany of the book of Isaiah (Isa 6) as a revelation of the pre-existent divine logos by understanding God's glory (LXX Isa 6.1) as the glory of Jesus. ${ }^{41}$ After the incarnation only the

39 It is almost a custom in Johannine studies to separate a 'profane' use of the word from a 'sacred'. The former being an ordinary term for inter human 'honour' and the latter having a specific theological meaning coined by John, which should be translated 'glory'. Many exegetes exclude the 'profane' use of the term from their interpretation. E.g. Thüsing, Erhöhung und Verherrlichung, 41-2, 199-201; Dietzfelbinger, Abschied des Kommenden, 283. However, in the following it will be argued that the two different understandings of $\delta$ ó $\xi \alpha$ in fact belong to a common idea. N. Chibici-Revneanu also includes all instances of $\delta$ ó $\xi \alpha$ in her treatise. She asks after every exegetical paragraph whether the instance of $\delta$ ó $\xi \alpha$ terminology is 'profan-anthropologische oder theologische $\delta$ ' $\xi \alpha$ (bzw. $\delta o \xi \dot{\alpha} \zeta \in 1 v)$ ?' and argues that the two are more related than is often claimed. Chibici-Revneanu, Herrlichkeit.

40 J. Frey takes the Johannine reference to Isaiah's vision to include both the temple vision (Isa 6) and the prophetic vision of the $\delta$ ó $\xi \alpha$ of the Suffering Servant (LXX Isa 52.13). For that reason the comment that Isaiah saw his $\delta$ ó $\xi \alpha$ does not refer to a pre-existent divine glory but to the glory of the crucified. Frey, 'Herrlichkeit', 386. But the fact that the reference to the $\delta$ ' $\xi \alpha-$ vision functions as the rationale for Isaiah's ability to predict the stubbornness of the Jews (12.40) makes it more likely that his prophetic calling in the temple is in view.

41 It is a characteristic Johannine feature to let quotations, metaphors, and traditions that in the Hebrew Bible concern God refer to Jesus. Cf. R. Zimmermann, 'Jesus im Bild Gottes. Anspielungen auf das Alte Testament im Johannesevangelium am Beispiel der Hirten Bildfelder in Joh 10', Kontexte des Johannesevangeliums. Das vierte Evangelium in 
privileged group of believers is able to see his glory. In the fundamental verse of incarnation (1.14) this particular group is marked out as 'we'. The mark of identity

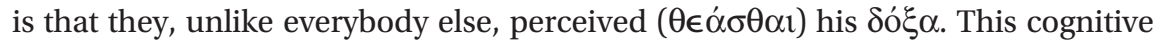
difference qualifies the social dichotomy in the preceding verses. One group did not receive him; another one believed in his name. The latter were privileged by becoming God's children. They are a divine breed, not born from human blood and flesh or the will of man but born from God (1.11-13). What distinguishes this group from other humans is their insight into the $\delta$ ó $\xi \alpha$ of Jesus despite his $\sigma \alpha ́ \rho \xi$. This 'we' already know what the persons in the Johannine story are about to realize. ${ }^{42}$ In the following half verse the $\delta o ́ \xi \alpha$ is further defined. It is a

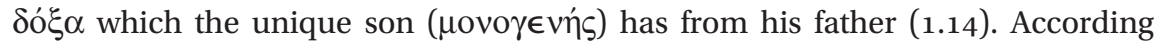
to the ancient household sons participate in the collective honour of the father and the only born son is the sole inheritor of his father's house and social position. ${ }^{43}$ The relation between the father, the only born son and $\delta$ ó $\xi \alpha$ in this verse suggests that this structure lies behind the expression. The only born son

religions- und traditionsgeschichtlicher Perspektive (ed. J. Frey and U. Schnelle [Hrsg. unter Mitarbeit von J. Schlegel]; WUNT 175; Tübingen: Mohr Siebeck, 2004) 81-116. On the use of the OT in the Fourth Gospel, see A. Obermann, Die christologische Erfüllung der Schrift im Johannesevangelium. Eine Untersuchung zur johanneischen Hermeneutik anhand der Schriftzitate (WUNT 2/83; Tübingen: J. C. B. Mohr [Paul Siebeck], 1996); M. J. J. Menken, Old Testament Quotations in the Fourth Gospel: Studies in Textual Form (Kampen: Kok, 1996). In this particular instance John's interpretation of Isa 6.1 is in line with a targumic tradition that interprets God's שול as his presence, his shekinah. In fact, in the Isaiah-Targum Isaiah sees the glory of God's shekinah. C. A. Evans, To See and Not Perceive: Isaiah 6.9-1o in Early Jewish and Christian Interpretation (JSOTSup 64; Sheffield: Sheffield Academic, 1989). It is not convincing, as C. A. Evans proposes, that John should be directly dependent on the Targum.

42 In Johannine studies it is a matter of dispute whether the 'we' in v. 14 (and 16) refers to the believing community or eyewitnesses. Seen from a narrative perspective, the 'we' $(1.14,16)$ includes the implied author and implied reader and constitutes an especially insightful level of communication which places the readers in a superior cognitive position compared to the narrative persons. Cf. Culpepper, Anatomy of the Fourth Gospel, 46.

43 Cf. J. H. Neyrey, The Gospel of John (NCBC; Cambridge: Cambridge University, 2007) 17. This interpretation seems more in line with the terminology than decidedly theological interpret-

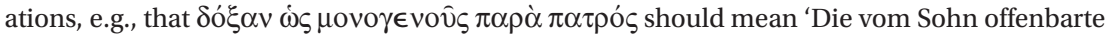
Herrlichkeit ist von 'einzigartiger' Heilsqualität, weil der Sohn seinen Ausgang ganz in Gott hat'. Schwindt, Gesichte, 416. On the antique household, see, e.g., C. Osiek and D. L. Balch, Families in the New Testament World: Households and House Churches (Louisville: Westminster John Knox, 1997). Social-historical commentaries of the Fourth Gospel include B. J. Malina and R. L. Rohrbaugh, Social-Science Commentary on the Gospel of John (Minneapolis: Fortress, 1998); Neyrey, The Gospel of John. Social-historical theories are applied to the Johannine concept of glory by Neyrey, The Gospel of John, 216-18; idem, 'Despising the Shame of the Cross: Honor and Shame in the Johannine Passion Narrative', Semeia 69 (1996) 113-37; idem, 'The Trials (Forensic) and Tribulations (Honor Challenges) 
has the same status as his father, which is moreover defined as being 'filled with grace and truth' (1.14). Generally, this description is understood as pointing to the OT depiction of God as being 'filled with mercy and truth' (e.g. Exod 34.6). ${ }^{44}$ If this is so, it is another argument for concluding that $\delta$ ó $\xi \alpha$ is the status and appearance that God's son shares with his father. $\delta$ ó $\xi \alpha$ is his divine identity.

That the pre-incarnational $\delta \delta^{\prime} \xi \alpha$ is not only a matter of superior status in an honour-shame system but also denotes the equivalent appearance is evident from the references to exceptional revelations of the pre-existent logos. According to the Fourth Gospel the logos is generally inaccessible before the incarnation but at a few theophanic events it appears in $\delta$ ó $\xi \alpha$. This is most explicitly stated in the already mentioned revelation to Isaiah (12.41), but probably also alluded to in the references to Abraham's vision (8.56-58) and the Sinai revelation (5.37-8). ${ }^{45}$ In these texts $\delta$ ó $\xi \alpha$ denotes the way of appearing that corresponds to the divine identity. What separates the Johannine references from the biblical tradition of God's כבוד/סó $\xi \alpha$ is only that it is transferred to the pre-existing logos.

After the incarnation the divine logos is accessible in Jesus (1.14). To perceive his $\delta o ́ \xi \alpha$ means to recognize his divine identity despite his human appearance. This insight separates the believing community from the rest of the human world (1.12-14). In the narrative middle Jesus' $\delta$ ó $\xi \alpha$ stands for his divine identity that may be recognized even though he appears in $\sigma \alpha ́ p \xi$. In this way the incarnation verse (1.14) sets up a fundamental structure for the entire Johannine narrative. In his earthly life Jesus' appearance does not correspond to his identity: he has divine status $(\delta o ́ \xi \alpha)$ but he appears as human ( $\sigma \alpha \dot{\alpha} \rho \xi)$. Only the believers perceive $(\theta \epsilon \alpha \dot{\alpha} \sigma \alpha \mathrm{l})$ his true identity ( $\delta$ ó $\xi \alpha)$ whereas the disbelieving humans only recognize his appearance $(\sigma \alpha \dot{\alpha} \xi)$. Because of the contradiction between identity and appearance the divine identity is not directly recognizable but demands a special insight which separates humans into two groups. The ones that have been given to Jesus by the father realize his divine identity (e.g. 17.6-8). The ones called 'Jews' take Jesus to be insane and dangerous claiming to be the son of God but actually being an ordinary man (e.g. 6.41-2; 8.48-59). The other way around it is just as important to Johannine theology that the divine $\delta$ ó $\xi \alpha$ is accessible in Jesus' $\sigma \alpha ́ \rho \xi$. As will be argued in relation to the resurrection appearances, it is Jesus' entire earthly existence that is his revelation of God. ${ }^{46}$ For that reason

of Jesus: John 7 in Social Science Perspective', BTB 26 (1996) 107-24; M. S. Collins, 'The Question of Doxa: A Socioliterary Reading of the Wedding of Cana', BTB 25 (1995) 100-109. 44 Cf. the history of research in A. T. Hanson, 'John I. 14-18 and Exodus XXXIV', NTS 23 (1977) 90-101.

45 On the allusions to Sinai in John 5, see N. A. Dahl, 'The Johannine Church and History', Current Issues in the New Testament Interpretation, FS O.A. Piper (ed. W. Klassen and G. F. Snyder; London: SCM, 1962) 124-42.

46 On the concept $\sigma \alpha ́ \rho \xi$ and its function in the Fourth Gospel, see Schwindt, Gesichte, 388-407. 
the contradiction between $\delta$ ó $\xi \alpha$ and $\sigma \alpha ́ p \xi$ does not imply a naïve docetism, as E. Käsemann famously claimed. ${ }^{47}$

In the middle of the Johannine narrative the complicated relation between Jesus' appearance and identity forms the basis for his activity. Jesus must convince humans of his divinity otherwise he cannot give them eternal life. He must disclose his hidden identity, that is, he must reveal his $\delta$ ó $\xi \alpha$. This is exactly what he does in his signs according to 2.11. Signs are tokens of his intimate relation to God and hence revelations of his divine identity. ${ }^{48}$ But the signs are not direct proofs of his identity. This is apparent from the fact that they are not received as signs by all spectators. Some people experience an extraordinary act, for example, the multiplication of bread, but do not perceive it as a sign of the divine status of the miracle maker (6.26). The disciples, on the other hand, see the signs as signifying Jesus' divinity (2.11). The divine character of $\delta$ ' $\xi \alpha$ in these contexts is evident from the fact that Jesus' $\delta$ ó $\xi \alpha$ is interchangeable with God's $\delta$ ó $\xi \alpha$. Jesus admonishes Martha before the resurrection of Lazarus. 'If you believe, you will see God's $\delta$ ' $\xi \alpha$ ' (11.40). God's $\delta o ́ \xi \alpha$ is perceivable in the resurrection of Lazarus because this sign reveals Jesus' divinity, just as his $\delta$ ' $\xi \alpha$ is perceivable in the wine miracle in Cana (2.11). Because Jesus' $\delta$ ó $\xi \alpha$ is the $\delta$ ó $\xi \alpha$ which the only born has from his father (1.14), it is identical with God's $\delta$ ó $\xi \alpha$. Consequently, the revelation of Jesus' $\delta$ ó $\xi \alpha$ in the signs is a revelation of his divinity.

According to 11.40 it takes a certain believing attitude to see the signs as a revelation of divine $\delta$ ó $\xi \alpha$. In 2.11, on the other hand, it may seem as if the revelation evokes faith. The schism between the two verses, however, need not be unbridgeable. ${ }^{49}$ They probably express the Johannine feature that Jesus, his words and his

47 E. Käsemann, Jesu letzter Wille nach Johannes 17 (Tübingen: J. C. B. Mohr [Paul Siebeck], 2d rev. ed. 1971) 61-2.

48 Larsen, Recognizing the Stranger, 112-24. According to J. Neyrey, Jesus, by manifesting his glory (2.11), made 'an honor claim, which the disciples acknowledge'. Neyrey, The Gospel of John, 64. But this statement shows that the Johannine understanding of $\delta$ ó $\xi \alpha / \delta o \xi \alpha \zeta \in 1 v$ cannot be adequately described in social-historical terms alone. It overlooks that Jesus' $\delta o ́ \xi \alpha$ is not just a hierarchical position within the common honour-shame system. He manifests his divine identity in the sign, which the disciples recognize when they believe in him.

49 Both recent monographs on the Johannine $\delta$ ó $\xi \alpha$ try to resolve the tension. According to N. Chibici-Revneanu faith is not a precondition for the revelation of Jesus' $\delta$ ó $\xi \alpha$ in the signs, but only to the believers is this $\delta$ ó $\xi \alpha$ identical with God's $\delta o ́ \xi \alpha$. Chibici-Revneanu, Herrlichkeit, 159. To R. Schwindt the statement in 11.4 expands the idea in 2.11 to a hermeneutic circle. The revelation of $\delta$ ó $\xi \alpha$ in the signs is an integral part of the unity between a believing understanding and the vision of $\delta$ ó $\xi \alpha$. Schwindt, Gesichte, 299. Among the other proposals to dissolve the tension between 2.11 and 11.40 is W. Bittner who claims that John relates signs, $\delta$ ó $\xi \alpha$, and faith, but is not interested in the way they are related. W. J. Bittner, Jesu Zeichen im Johannesevangelium. Die Messias-Erkenntnis im Johannesevangelium vor ihrem jüdischen Hintergrund (WUNT 2/26; Tübingen: J. C. B. Mohr [Paul Siebeck], 1987) 99. C. Welck insists that Jesus' $\delta$ ó $\xi \alpha$ is only visible to the believers after the passion. For that 
works, reveal not only his own identity but also the identity of the people who encounter him. ${ }^{50}$ Without explanation some people are sympathetic towards him, and some people are not. To the first group the signs are revelations that cause faith, to the second group they are not signs at all. The point is not whether signs evoke or demand faith, but rather that to some people they are revelations of Jesus' $\delta$ ' $\xi \alpha$ and to some they are not. Jesus' miracles expose who humans are. The shepherd discourse expresses this idea symbolically when the sheep of the shepherd know his voice $(10.4-5,16)$. The difference between the two kinds of sheep is established by the voice of the shepherd; before he called his sheep there was no distinction between the two groups. His voice constitutes the two groups because their reaction to his calling is the only way to tell who his sheep are. Both the signs and the shepherd discourse show that Jesus' actions reveal who people are.

If Jesus as the only born son had divine status with God his father before the creation of the world, and he reveals his divinity to humans during his earthly life, it is almost logical that the people who perceive his status are included into it. Just as God and Jesus, as father and son, share the same $\delta$ ó $\xi \alpha$, so Jesus gives the believing humans his $\delta$ ó $\xi \alpha$ (17.22) which includes them into the divine commu-

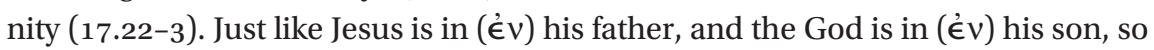
the believers will be in ('́) $v$ ) the father and the son $(10.30,38 ; 14.10-11) .{ }^{51}$ In being included into the relation between father and son the believers become parts of the divine household as Jesus' brothers (20.17) and children of God (1.13). ${ }^{52}$ Consequently, they take over Jesus' obligations through their relation to him. Jesus loves the father and keeps his command (10.17-18; 14.31; 15.10; 17.23); so the disciples will love Jesus and keep his command $(14.15,21,23 ; 15.9-10$; 17.23). Jesus is sent to the world by the father; so he sends his disciples to the world $(17.18 ; 20.21)$. From the unity between the son and the father the world should believe that Jesus is sent by God; so from the unity of the community the world should realize that Jesus is sent and loved by the father (17.23). Just as Jesus is not from the world, his disciples are not from the world $(17.14,16)$. It could even be said that the disciples in their earthly existence do not have

reason 2.11 concerns the belief of the reader. Welck, Erzählte Zeichen, 89. All proposals seem to neglect the radicalism in the Johannine conception of revelation.

50 Cf. G. Hallbäck, 'The Gospel of John as Literature: Literary Readings of the Fourth Gospel', New Readings in John: Literary and Theological Perspectives (ed. J. Nissen and S. Pedersen; JSNTSup 182; Sheffield: Sheffield Academic, 1999) 31-46 (esp. 45).

51 On this so called 'reciprocal immanence', see K. Scholtissek, In ihm sein und bleiben. Die Sprache der Immanenz in den johanneischen Schriften (HBS 21; Freiburg: Herder, 2000).

52 Cf. J. G. van der Watt, The Family of the King: Dynamics of Metaphor in the Gospel according to John (Leiden: Brill, 200o); M. L. Coloe, Dwelling in the Household of God: Johannine Ecclesiology and Spirituality (Collegeville, MN: Liturgical, 2006). 
the appearance that corresponds to their status as children of God, just like Jesus loses his divine appearance in the incarnation. Probably, the final part of Jesus' last prayer (17.24-26) predicts an eschatological situation in which the believers in line with apocalyptic ideas will be unambiguously included in the divine $\delta$ ó $\xi \alpha$ and contemplate ( $\theta \epsilon \omega \rho \in \hat{i} v)$ Jesus' $\delta o ́ \xi \alpha .{ }^{53}$

The result of Jesus' revelation of his $\delta$ ó $\xi \alpha$ on earth is that the believers in spite of their human appearance are incorporated into his $\delta$ ' $\xi \alpha$ and experience the same contradiction between appearance and identity as him. This corresponds to the fact that the Johannine Jews do not seek $\delta$ ó $\xi \alpha$ from God but want it from each other $(5.44 ; 12.43)$. It is not possible to hold a high status position in both the Jewish honour system and in relation to God. As both verses put it, it is impossible to believe when the $\delta$ ó $\xi \alpha$ from humans and not the $\delta$ ó $\xi \alpha$ from God is the centre of attention. In accordance with some sapiential ideas (cf. Sir 4.21; Est 4.21), the Fourth Gospel separates status within a human hierarchy from the divine status that the believers are given. The two kinds exclude each other. To achieve status from God means to accept being disqualified in the ordinary social hierarchy as Jesus predicts will happen to the disciples (16.2).

Consequently, Jesus does not seek $\delta$ ó $\xi \alpha$ for himself $(5.41 ; 7.18 ; 8.50,54)$. If he did so, he would be promoting himself trying to achieve a higher position in the social hierarchy, which would be an accepted behaviour within the ordinary social system (5.43). But this is not what he does. He seeks recognition for his father, not for himself (7.18). Being sent from the father he is not supposed to speak on his own behalf or improve his own position but to achieve recognition for the authority behind his mission. The one who should recognize him is the one that has sent him, namely, God himself. ${ }^{54}$ Jesus is not interested in status within the human hierarchy and if he would give himself status it would not be of any value $(8.50,54)$. For Jesus personally it is only the recognition from God that matters, and his entire existence has the purpose of letting God be recognized. He seeks $\delta$ ó $\xi \alpha$ for him both in his speeches and in his deeds which can be

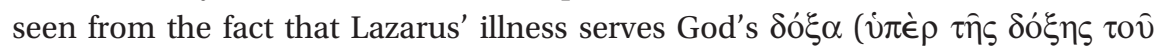
$\theta \in \mathrm{O} \hat{)})$ (11.4). Lazarus' illness serves this end because it allows Jesus to reveal

53 N. Chibici-Revneanu insists that this eschatological vision is different from the visions of Jesus' $\delta o ́ \xi \alpha$ during his earthly life $(2.11 ; 11.40)$. She argues that the conditions for the vision have changed so that the vision itself is different; and that Jesus' $\delta$ ó $\xi \alpha$ now can be seen in its complete unity with the father. Chibici-Revneanu, Herrlichkeit, 302. The distinction between appearance and status is a simple way to account for the difference between earthly and eschatological visions.

54 Cf. J.-A. Bühner's presentation of the Jewish representational system. Bühner, Der Gesandte und sein Weg, 181-267. The envoy represents the sender in such a way that the recipients are dealing with the sender himself through the messenger. It would be a complete misunderstanding if the recipients recognize the envoy in his own right. On the contrary, only the one that has sent him can evaluate his worth as a messenger. 
God's glory in the sign (11.40) and thereby cause recognition of God (cf. 11.42). When faith arises in connection with the sign, God's identity is recognized and hence Lazarus' illness has proven not to be to death but to serve God's status as God (11.4). This point is also expressed with Johannine irony in the remarks of the Jews that the healed man born blind should give $\delta$ ó $\xi \alpha$ to God (9.24). On the level of the Johannine Jews this means to accept that Jesus has not cured him, but on the level of the Johannine readers the man does give $\delta$ ó $\xi \alpha$ to God when he insists that Jesus has performed the miracle. ${ }^{55}$

To sum up on the use of the noun $\delta$ ó $\xi \alpha$, two basic semantic fields of the word dominate the Johannine terminology as they do in contemporary literature. $\delta$ ó $\xi \alpha$ denotes a divine appearance which Jesus has before and after the incarnation, that is, in the narrative beginning and end. During his earthly life, that is, the narrative middle, he appears in $\sigma \alpha ́ \rho \xi$. But $\delta$ ó $\xi \alpha$ also designates status, both a divine status and a social hierarchical status. Jesus and God have divine $\delta$ ó $\xi \alpha$ and the believing humans receive it from Jesus. The Jews, on the other hand, seek social status from each other. To give or receive $\delta$ ó $\xi \alpha$ means to enhance or recognize a hierarchical position. This happens in the social negotiations between humans when they recognize each other. But it happens in another way when the disciples achieve a position in the divine relationship between father and son and thereby take part in their status. These two ways of achieving recognition exclude each other. Jesus does not want any recognition for himself because he acts as God's representative in order to win recognition of him. The believers renounce human recognition in order to obtain recognition from God.

\subsection{Glorification in the Narrative Structure}

The verb $\delta o \xi \alpha \dot{\alpha} \in \mathfrak{l} v$ takes up the meaning of the expression 'to give $\delta$ ' $\xi \alpha$ ' but interprets it in a sophisticated way. Every positively portrayed person or group of persons in the Fourth Gospel is in some way involved in glorification. Jesus and God are related in mutual glorification, and humans are related to the divine community when they or the Paraclete glorify God and Jesus. The question is what the content of these relations is, and how the glorification relates the participants to each other in the community of God, Jesus, the Paraclete, and the believers. Nowhere are the different forms of glorification so intimately related as in 13.31-32. For that reason this pericope will conclude the exegesis.

God's glorification of Jesus divides time into two: before and after the glorification when Jesus re-enters into the divine $\delta$ ó $\xi \alpha(7.39 ; 12.16) .{ }^{56}$ This is confirmed

55 Cf. P. D. Duke, Irony in the Fourth Gospel (Atlanta: John Knox, 1985) 78; Chibici-Revneanu, Herrlichkeit, 139-40.

56 Among many others N. Chibici-Revneanu rejects a separation of death and glorification. 'Eine zeitliche Ausdifferenzierung zwischen Tod und (darauf folgender) "Verherrlichung" hat jedoch m. E. keinen Anhalt am Text'. Chibici-Revneanu, Herrlichkeit, 174. She does not take into account that the results of the glorification, viz. the disciples' understanding of 
by Jesus' petition that God should glorify him with the $\delta$ ó $\xi \alpha$ he had with him before the creation of the world (17.5). Furthermore the glorification of Jesus is placed in the Johannine 'hour' that denotes the time around the crucifixion (12.23; cf. 13.1; 17.1). ${ }^{57}$ From these verses it is clear that God's glorification of Jesus is the vindication of him after the crucifixion which consists of a re-establishment of the position he had before his incarnation. ${ }^{58}$ In the glorification Jesus re-gains the divine appearance in which he later on appears to the disciples. ${ }^{59}$ This glorification is radically different from a contribution of $\delta$ ó $\xi \alpha$ that Jesus himself may provide because it is God's response to his fulfilled work (8.54).

According to the narrative structure the glorification of Jesus introduces the end phase of the gospel where the resurrected Jesus immediately calls forth the recognition he sought in his earthly life. But the transition to the narrative

scripture (12.16) and the advent of the Spirit-Paraclete (12.16), in other places are results of the resurrection $(2.22)$ and the transition to the father $(15.26 ; 16.7)$. In the text the cross is not connected to these events.

57 The Johannine $̋ \rho \alpha$ is not just the crucifixion but the series of events in the passion narrative. Frey, Eschatologie II, 215-21.

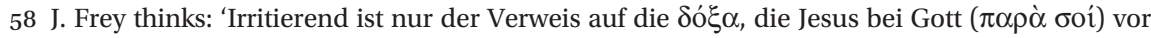
Grundlegung der Welt schon hatte (Joh 17.5). Sollte die Verherrlichung Jesu in "seiner Stunde" nichts "Neues" bringen, nur die Wiedereinsetzung in eine vormalige $\delta$ ó $\xi \alpha$ ? Und was für eine $\delta o ́ \xi \alpha$ sollte dies sein?' Frey, 'Herrlichkeit', 389. According to the distinction between appearance and identity the answer is that it is an appearance that corresponds to his identity. The 'new' in this glorification is its role in the narrative structure: 'In Rahmen des Gesamtentwurfes wird damit die Passion zur letztgültigen Bestätigung der Zugehörigkeit Jesu zum Vater, und in solcher Zugehörigkeit besteht seine Doxa von Anfang an'. Dietzfelbinger, Abschied des Kommenden, 289. N. Chibici-Revneanu distinguishes 'zwischen $\delta$ ó $\xi \alpha \pi \alpha \rho \grave{\alpha} \pi \alpha \tau \rho o ́ \varsigma$ einerseits und $\delta$ '́ $\xi \alpha \pi \alpha \rho \grave{\alpha} \pi \alpha \tau \rho$ i andererseits'. The glorification of Jesus 'markiert den Übergang von der $\delta o ́ \xi \alpha \pi \alpha \rho \grave{\alpha} \pi \alpha \tau \rho o ́ \varsigma$ zur $\delta o ́ \xi \alpha \pi \alpha \rho \grave{\alpha} \pi \alpha \tau \rho i^{\prime}$. Chibici-Revneanu, Herrlichkeit, 325-6. Through this distinction she stresses the unity of the concept of glory throughout the gospel. This legitimate project would, however, gain clarity from the distinction between $\delta$ ó $\xi \alpha$ as appearance and $\delta$ ó $\xi \alpha$ as identity.

59 This understanding corresponds to the interpretation of the 'noli me tangere'-scene that the resurrected Jesus is in a liminal state until he is transformed to a divine pneumatic status. D'Angelo, 'A Critical Note'; H. W. Attridge, “Don't Be Touching Me”: Recent Feminist Scholarship on Mary Magdalene', in A Feminist Companion to John, vol. 2 (ed. A.-J. Levine and M. Blinckenstaff; Cleveland: Pilgrim, 2003) 140-66; G. Buch-Hansen, 'It is the Spirit that Gives Life': A Stoic Understanding of Pneuma in John's Gospel (BZNW 173; Berlin etc.: De Gruyter 2010) 353-404. But exactly because Jesus is in an intermediate status Mary first does not recognize him and mistakes him for an ordinary human (20.15), then she thinks he is the earthly person that she used to know as a teacher (20.16), and finally Jesus tells her to keep a distance (20.17). Compared to the full recognition by the male disciples, who are invited to see and touch Jesus' body $(20.20,27)$, it is hard to follow the conclusion that the scene is meant to illustrate an especially intimate relation between Jesus and Mary. Against D'Angelo, 'A Critical Note', 535-6. 
middle is described as a glorification as well, as can be seen from the idea of God glorifying his name (12.28). When Jesus requests God to glorify his name, it means that God should bring forth the recognition of his own authority behind Jesus which is at the same time a recognition of God himself as revealed in Jesus (cf. 5.43 ; 10.25). God's answer to Jesus' prayer, however, refers to a glorification that has taken place ('́㇒́ $\delta \alpha \sigma \alpha)$ and a glorification that will take place

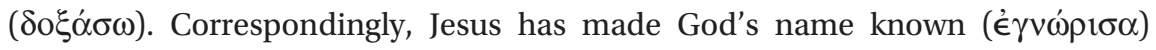
and will make it known ( $\gamma \nu \omega \rho i \sigma \omega)$ (17.26). ${ }^{60}$ Both statements signify that Jesus first has revealed God in his earthly life and thereby glorified God's name. Secondly, he will continue to do so when he completes his task on the cross and appears as resurrected to the disciples. God has glorified his name by sending Jesus to find recognition among humans who believe in his name (1.12; 2.23 ; 3.18 ; cf. 17.11-12). He will glorify himself by completing this quest through the final vindication of the son. ${ }^{61}$ For that reason it is only logical that Jesus demands his father to glorify his son so that he can glorify the father (17.1). The glorification of the son will, as stated above, lead into immediate recognition and thereby God will be glorified. There is a mutual dependence between the glorification of father and son. God is glorified in the earthly activity of Jesus, but he also must glorify him in order to be glorified himself.

When Jesus glorifies God, the same structure is involved. On the one hand he glorifies God by fulfilling the work that he has been given to do (17.4). On the other hand he needs to be glorified to glorify his father (17.1). The double character of the glorification of God corresponds to the narrative structure. Jesus glorifies God when he fulfils his work on earth by revealing him to humans, thereby seeking recognition of him. But this recognition is not complete until Jesus himself is glorified and can appear unambiguously to his disciples. The overall content of Jesus' glorification of God is to provide humans' recognition of him as revealed in Jesus' deeds and words. Whenever this happens, God is glorified through him (14.13). ${ }^{62}$

60 Not many commentators notice this parallel because they fail to see the relation between glorification and revelation (e.g., Frey, 'Herrlichkeit', 388).

61 The relation between the different verb forms (aorist, future) causes problems for exegetes. Some refer the aorist to the revelation in the signs and the future to the passion. E.g. C. K. Barrett, The Gospel according to St John (London: SPCK, 2d rev. ed. 1978) 426. Others deny the difference and interpret the verbs as a reference to the continuing glorification. E.g. R. Schnackenburg, Das Johannesevangelium. II. Teil (HThKNT 4; Freiburg etc.: Herder, 1971) 486. Again others let the aorist be 'punctiliar' and refer to the 'hour' whereas the future points to the fate of the disciples after Easter. E.g. M. Pamment, 'The Meaning of doxa in the Fourth Gospel', ZNW 74 (1983) 12-16 (esp. 13); cf. Chibici-Revneanu, Herrlichkeit, 187; Thüsing, Erhöhung und Verherrlichung, 194-8. On the basis of the fundamental narrative structure of the gospel it seems possible to relate the verbs to two different acts.

$62 \mathrm{~N}$. Chibici-Revneanu calls this 'Erwachsen eines menschlichen $\delta$ o $\xi \alpha \dot{\zeta} \in \in \mathrm{v}$ aus dem

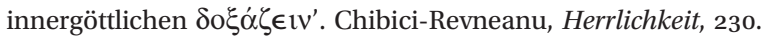


The glorification by a third party follows the presented structure. It consists of recognizing Jesus as God's son and authorized revealer and God as Jesus' father. It happens when humans become Jesus' disciples, and act accordingly (15.8; 17.10; $\left.21.19^{63}\right)$, when Lazarus' illness provokes recognition of Jesus' divine authority (11.4), and when the Paraclete carries on Jesus' revelation (16.14). In all cases God and/or Jesus (which one makes no difference in these contexts) are recognized.

On the basis of these interpretations 13.31-2 proves to be in accordance with the Johannine understanding of glorification. At the point in time when Judas has left to start the chain of events that leads to Jesus' crucifixion, Jesus is alone with his disciples and proclaims that he is glorified. It means that he has found recognition among his disciples. In this God is glorified because his authority has been recognized through Jesus. When this has happened, Jesus has concluded his task on earth and for that reason God will glorify him by letting him re-enter into his divine appearance. ${ }^{64}$

\section{Concluding Interpretation of the Narrative Structure}

It is apparent that the Johannine use of $\delta$ ó $\xi \alpha / \delta o \xi \dot{\alpha} \zeta \in 1 v$ follows the narrative structure of the gospel and at the same time interprets the traditional content of the terms in an innovative manner. The semantic field of the Johannine concept of $\delta$ ó $\xi \alpha$ basically denotes divine identity both in a manifest (appearance) and a latent (status) form. Consequently 'to give $\delta$ 'o $\xi \alpha$ ' and $\delta$ o $\xi \alpha \zeta \in \mathfrak{\alpha}$ mean to recognize somebody's identity, or to provide a superior status or the corresponding appearance. The Fourth Gospel uses both meanings in a sophisticated way to express different elements of the narrative structure.

Jesus has divine identity as the son of God and he has the corresponding appearance in the beginning and end of the narrative, that is, before and after his incarnation. He is glorified by God when he regains this appearance after

6321.19 is atypical for the Fourth Gospel because a specific act-and not recognition as suchglorifies God. Still, Peter's martyr death is an expression of his adherence to the recognition of Jesus and God.

64 The relation of the different glorifications has produced a great deal of exegetical difficulties. At the same time the verses are central to several important interpretations. To W. Thüsing it is the prime witness to his two-stage-theory. The earthly glorification is only a prefiguration ('Bild') of the real glorification which will take place after Jesus' resurrection. Thüsing, Erhöhung und Verherrlichung, 235, 239. The temporal confrontation of past and future has also been a prime example of the so-called Johannine fusion of horizons ('Horizontverschmelzung'). According to this idea the verbs refer to the same events but aorist forms are seen in retrospective whereas the future forms in prospective. Frey, Eschatologie II, 135-6; Frey, 'Herrlichkeit', 388-9; cf. Chibici-Revneanu, Herrlichkeit, 213. Neither of these interpretations takes the narrative structures into account. 
his death and resurrection. In the middle part $\delta o \xi \dot{\alpha} \zeta \in i v$ describes the purpose of Jesus' earthly life. He is to establish recognition of God when he seeks recognition of his identity as son of God which includes recognition of God's identity as his father. He does so by revealing his divine identity in words and deeds. Recognition of this is glorification of him and his father, and it continues whenever humans believe in him. However, full recognition is not possible until Jesus appears in accordance with his divine being. For that reason his glorification by God is the necessary precondition for achieving the recognition he was sent for, namely, the glorification of God. This recognition brings humans into the relation between father and son; they receive the status that is common to the divine community with a promise of a future direct vision of the divine $\delta$ ó $\xi \alpha$.

The incorporation of the Johannine $\delta$ ó $\xi \alpha$-concept in the plot of the gospel has consequences for the understanding of the Johannine version of the story of Jesus. It is an established understanding that the Fourth Gospel depicts Jesus in retrospect ('nachösterlich') in so far as the story is told with a cognitive competence that was not available before Jesus' glorification and the advent of the SpiritParaclete $(2.22 ; 7.39 ; 12.16 ; 14.26 ; 20.9) .{ }^{65}$ In his highly inspirational work Jörg Frey endorses this view of the Johannine technique. ${ }^{66}$ But he takes it a step further by letting the cognitive competence of the narrator include the Johannine narrative itself. 'Daraus folgt aber, dass die sich in Jesu Zeichen offenbarende Herrlichkeit jene $\delta$ ó $\xi \alpha$ ist, die Jesus in "seiner Stunde" zuteil wurde und die selbst seine Jünger erst später erkannten, die aber nun-in der rückblickenden Darstellung des Evangeliums-auch die Episoden auf seinem Erdenweg umglänzt'. ${ }^{67}$ What according to Frey happens in the end is already present in the beginning and middle of the Johannine narrative.

Frey's interpretation, however, does not comply with classical demands for a whole and complete narrative. If the result of a narrative plot is already present in all phases of the narrative, the narrative beginning, middle, and end collapse. According to Aristotle's Poetics this dissolves the plot. Frey is right about the hermeneutic process behind the Fourth Gospel but the Johannine narrative itself is not included in the retrospective reflection. ${ }^{68}$

65 Cf., e.g., C. Hoegen-Rohls, Der nachösterliche Johannes. Die Abschiedsreden als hermeneutischer Schlüssel zum vierten Evangelium (WUNT 2/84; Tübingen: J. C. B. Mohr [Paul Siebeck], 1996).

66 'Diese Darstellungsweise lässt sich als seine Form der nach johanneischer Überzeugung durch den Geist inspirierten "Erinnerung" begreifen, in der den Zeugen im nachösterlichen Rückblick die wahre Bedeutung des Wirkens und Geschickes Jesu sowie der Schriftaussagen über ihn erschlossen wurde'. Frey, 'Herrlichkeit', 394; cf. Frey, Eschatologie II, 247-83.

67 Frey, 'Herlichkeit', 394.

68 'Ganz gleich, wie hoch die Kenntnis und Benutzung der Synoptiker im Joh veranschlagt wird-dieses Werk zeigt gegenüber den Synoptikern ein fortschrittenes Stadium der 
Indeed, the Fourth Gospel does represent an advanced state of Christological development but its consideration of Jesus' story (on the basis of one or more of the synoptics) results in an innovative interpretation presented in a new but whole and complete plot. The narrative course is constituted by God's wish to be recognized through Jesus. To express this structure the evangelist uses $\delta$ ó $\xi \alpha / \delta o \xi \alpha \dot{\alpha} \zeta \in 1 v$ in a way that is rooted in the concept's Hellenistic Jewish semantic potential but at the same time formed by the Johannine plot. In the narrative structures of the

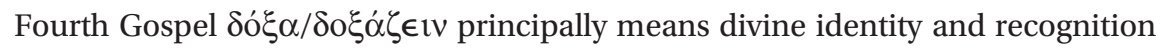
of this identity. 